\title{
GAMBARAN STIGMA MASYARAKAT TENTANG COVID-19 DI KEPANJEN MALANG
}

\section{Description Of Community Stigma About Covid-19 In Kepanjen Malang}

\section{Yuyud Wahyudi ${ }^{\text {** }}$}

\section{Lilis Sulistiya Nengrum²}

Fera Sartika ${ }^{3}$

\author{
*ISTIKes Widya Cipta Husada, Malang, \\ Indonesia \\ 2STIKes Widya Cipta Husada, Malang, \\ Indonesia \\ 3Universitas Muhammadiyah \\ palangkaraya, Indonesia \\ *email: lilissulistiya0 I@gmail.com
}

\begin{abstract}
Abstrak
Stigma merupakan tanda yang dibuat pada tubuh seseorang untuk diperlihatkan dan menginformasikan kepada masyarakat bahwa orang yang mempunyai tanda tersebut merupakan ungkapan ketidakwajaran dan keburukan status moral yang dimiliki seseorang tersebut. Tujuan penelitian ini adalah mengetahui stigma masyarakat tetang COVID-19 di Kelurahan Cepokomulyo Kecamatan Kepanjen Kabupaten Malang. Desain penelitian yang digunakan adalah metode deskriptif dengan pendekatan cross sectional. Teknik sampling penelitian ini adalah Cluster Sampling sebanyak 364 responden yang diberikan pertanyaan berupa kuesioner Variabel stigma masyarakat (tanda dan isyarat, sterotip, prasangka, diskriminasi) Hasil Uji Validitas kuesioner menggunakan ICVI (content validity index) didapatkan nilai 0,935 dinyatakan valid. Uji Reliabilitas dari seluruh kuesioner yang telah diisi oleh responden didapatkan hasil. Tanda dan isyarat 0,829 , Sterotip 0,805 , Prasangka 0,850 dan Diskriminasi 0,802 reliabel. Hasil penelitian ini dari 4 variabel mendekati kategori baik dengan nilai skor prosentase tertinggi terletak pada variabel sterotip yaitu sebanyak $94,2 \%$ $(n=364)$ dapat diartikan bahwa stigma masyarakat berkategori baik, dikarenakan masyarakat tidak menilai orang hanya dari penampilannya saja. Kesimpulan masyarakat tidak memberikan stigma yang buruk tentang adanya penyakit seperti COVID-19 ini, dengan adanya komunikasi yang baik dan mendapatkan informasi yang benar maka stigma yang buruk tidak akan muncul di lingkungan masayarakat.
\end{abstract}

\section{Kata Kunci:}

Stigma

Tanda dan Isyarat

Sterotip

Prasangka

Diskriminasi

\section{Keywords:}

Stigma

Sign and Cues

Steroptypes

Prejudice

Discrimination

\begin{abstract}
Stigma is a sign that is created on human body to be shown and to inform the public that a person who has that sign constitutes no morals and primness expression which is belong to someone. The purpose of this study is understanding society stigma about Covid 19 in Cepokomulyo Village, Kepanjen sub-district Malang regency. Research design used in this research is descriptive method and cross sectional approach. The sampling technique in this research uses Cluster Sampling as many as 364 respondents. The respondents were given questionnaire by researcher, it is a questionnaire variable of society stigma ( sign, signal , stereotypes, prejudice, and discrimination) to validate the data. In validating questionnaire, the researcher used ICVI (content validity index). And the data is stated valid with a score 0,935. Reliability test from all the questionnaires which had been fullfill by the respondents gave the results, those are signal/cues 0,829 , Stereotypes 0,805 , prejudice 0,850 and discrimination 0,802. The result of the research, there are 4 variables that means a good categories. The percentage highest scores lies in stereotypes variable as many as $94,2 \%(n=364)$, it means the societys stigma is good.Because the society does no judge the people by appearance. The conclusion, the society did not give a bad stigma about Covid 19. A good communication and ght information can be solution to build up society stigma about covid 19. And the bad stigma would not show up in society.
\end{abstract}




\section{PENDAHULUAN}

Penyakit Coronavirus 2019 (disingkat "COVID19") adalah penyakit pernapasan yang muncul yang disebabkan oleh coronavirus baru dan pertama kali terdeteksi pada Desember 2019 di Wuhan, Cina. Penyakit ini sangat menular, dan gejala klinis utamanya termasuk demam, batuk kering, kelelahan, mialgia, dan dispnea (Zhong B-L, Luo, 2020). WHO telah menamai penyakit akibat Virus Corona jenis baru ini sebagai COVID-19, di Dunia yang terinfeksi COVID-19 sejumlah 4,35 juta dari jumlah tersebut 297,552 dinyatakan meninggal dunia dan I,55 dinyatakan sembuh. Amarika Serikat menduduki peringkat pertama sebagai Negara yang memiliki kasus terbesar yang mencapai I.427.739 dengan 85.04I kematian dan 307.836 pasien sembuh (Kemenkes RI, 2020).

Coronavirus adalah suatu kelompok virus yang dapat menyebabkan penyakit pada hewan atau manusia. Beberapa jenis coronavirus diketahui menyebabkan infeksi saluran nafas pada manusia mulai dari batuk pilek hingga yang lebih serius seperti Middle East Respiratory Syndrome (MERS) dan Sereve Acute Respiratory (SARS). COVID-I9 adalah penyakit menular yang disebabkan oleh jenis coronavirus yang baru ditemukan, ini merupakan virus dan penyakit yang sebelumnya dikenal sebelum terjadi wabah di wuhan, Tiongkok bulan Desember 2019 (Yurianto, 2020).

Keadaan darurat kesehatan masyarakat, seperti COVID19 dapat menyebabkan stigma orang, tempat, dan hal-hal yang diyakini terkait dengan virus. Stigma dapat berakibat pada konsekuensi emosional atau kesehatan mental negative terhadap mereka yang distigmatisasi dan menciptakan lingkungan ketidak percayaan atau kemarahan umum dalam satu komunitas, mengetahui fakta dan membagikan kepada orang-orang dapat membantu mengurangi stigma (Korte, 2019). Stigma merupakan tanda yang dibuat pada tubuh seseorang untuk diperlihatkan dan menginformasikan kepada masyarakat bahwa orang-orang yang mempunyai tanda tersebut merupakan seorang budak, kriminal atau seorang penghianat serta suatu ungkapan ketidakwajaran dan keburukan status moral yang dimiliki oleh seseorang, stigma ini mengacu kepada atribut yang memperburuk citra seseorang (Purnama, 20l6).

Stigma social dalam konteks kesehatan adalah hubungan negatif antara seseorang atau kelompok orang yang berbagai karakteristik tertentu dan penyakit tertentu. Stigma sosial adalah penolakan keberadaan seseorang atau kelompok pada lingkungan tertentu karena sudah dianggap tercela, dampak stempel stigma berujung pada pengucilan di lingkungannya. Dalam wabah, ini mungkin orang dirawat secara terpisah, terhadap kelompok (distreotipkan), berdasarkan karakteristik (didiskriminasi) atau mengalami kehilangan status karena dianggap memiliki hubungan dengan suatu penyakit. Wabah COVID-19 saat ini telah memprovokasi stigma social dan perilaku diskriminasi terhadap orang-orang dari latar belakang kelompok tertentu serta siapapun yang dianggap telah melakukan kontak dengan virus (WHO, 2020).

Perlakuan masyarakat yang kurang baik dan berfikir negatif dapat memperburuk seseorang, misalnya seperti seseorang yang mengenakan masker akan dicurigai memiliki gejala COVID-19. Padahal kenyataan di lapangan setiap seseorang mempunyai alasan untuk memakai masker. Hindari penyebaran informasi yang salah tetap terinformasi melalui sumber terpercaya, seperti pusat pengendalian penyakit dan Organisasi Kesehatan Dunia. Perbaiki informasi yang salah dengan sopan dan perilaku yang distigmatisasi meningkatkan rasa takut dan membuat kita semua kurang aman (Korte, 2019).

Hasil dari wawancara ke Kepala Desa Cepokomulyo Kecamatan Kepanjen Kabupaten Malang, mewawancarai 10 orang di Kelurahan Cepokomulyo, dimana 8 orang warga mengetahui COVID-19 secara umum dan dari masyarakat didapat tentang warga yang positif COVID-I 9 dan ODR (orang dengan resiko), warga masih kawatir dengan warga yang positif dan warga yang baru datang dari luar kota, masyarakat masih menganggap orang yang dari luar kota dapat menularkan virus ini, kemudian menjadi pembicaraan negatif di lingkungan serta masyarakat masih takut dengan adanya COVID-19. 
Adapun dari peran perawat juga menjelaskan tentang pemantauan orang dengan resiko (ODR) menggunakan Whatsapp (WA). Petugas kesehatan juga menjelaskan untuk masalah stigma perawat sudah melakukan upaya memerangi stigma dengan melakukan pendidikan kesehatan, namun saat ini belum ada penelitian untuk menggambarkan stigma yang ada dimasyarakat.

\section{METODE PENELITIAN}

Jenis penelitian ini yang digunakan adalah deskriptif dengan menggunakan pendekatan cross sectional dengan tujuan untuk mengetahui gambaran stigma masyarakat tentang COVID-1 9 di Kepanjen Malang

\section{HASIL DAN PEMBAHASAN}

\section{HASIL}

\section{Distribusi Karakteristik Responden}

Tabel I. Distribusi frekuensi responden berdasarkan umur $(n=364)$

\begin{tabular}{ccc}
\hline Usia & Frekuensi & Presentase \\
$18-28$ & 130 & $35.7 \%$ \\
\hline $29-40$ & 234 & $64.3 \%$ \\
\hline Total & 364 & $100.0 \%$ \\
\hline
\end{tabular}

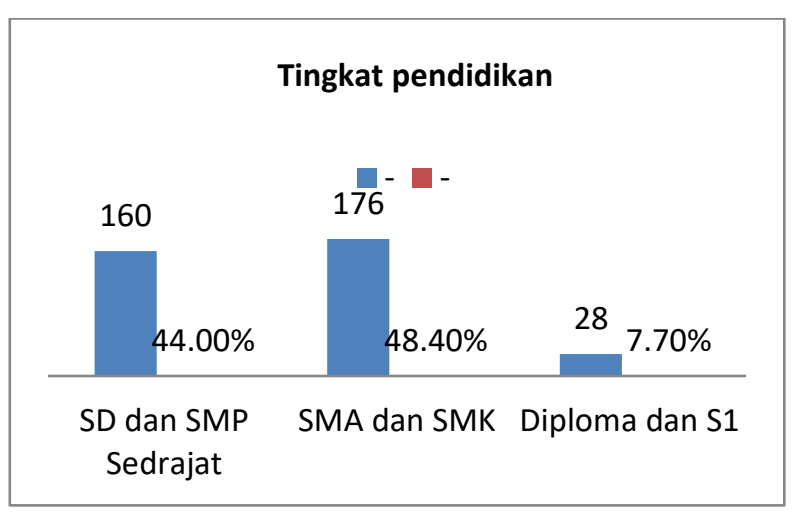

Gambar I. Distribusi Responden Berdasarkan tingkat Pendidikan

\section{Analisis Univariat}

Gambaran Stigma Masyarakat Tanda dan Isyarat tentang COVID-I9 di Kelurahan Cepokomulyo Kecamatan Kepanjen Kabupaten Malang
Tabel II. Hasil distribusi frekuensi responden berdasarkan stigma masyarakat tanda dan isyarat tentang COVID-19 di Kelurahan Cepokomulyo Kecamatan Kepanjen Kabupaten Malang $(n=364)$

\begin{tabular}{|c|c|c|c|}
\hline Variabel & $\begin{array}{c}\text { Katagori } \\
\text { / Skor }\end{array}$ & Frekuensi & $\%$ \\
\hline $\begin{array}{c}\text { Tanda } \\
\text { dan } \\
\text { Isyarat }\end{array}$ & Baik & 308 & $84,6 \%$ \\
\hline & Kurang & 56 & $15,4 \%$ \\
\hline Total & & 364 & $100 \%$ \\
\hline
\end{tabular}

Sumber data : Data Primer juli 2020

Berdasarkan hasil penelitian dari 364 responden dapat diketahui bahwa tingkat stigma tanda dan isyarat masyarakat yang memiliki stigma baik 308 (84,6 \%) dan masyarakat yang memiliki stigma kurang 56 (18,4\%), Median 7,00. Tanda dan isyarat, pembedaan dan memberikan tanda atau penamaan berdasarkan perbedaan-perbedaan yang dimiliki anggota masyarakat tersebut.

Berdasarkan hasil penelitian Vramita, menyatakan bahwa label atau tanda memberikan efek negatif yang kuat terhadap cara individu lain bereaksi emosional pada setiap individu sehingga meningkatkan preferensi untuk jarak sosial (Varamitha, 2016). Pada penelitian Ariananda, tanda isyarat sebuah tindakan disebut perilaku menyimpang karena masyarakat lain memakai atau menamainya (tanda atau label) sebagai perilaku menyimpang. Penyebutan sebuah tindakan perilaku menyimpang sangat tergantung pada proses definisi dan tanggapan seseorang itu sendiri terhadap sebuah tindakan. Tanda dan isyarat ini pemberian cap atau label terhadap seseorang yang sudah dicap oleh masyarakat, kepada orang yang diberikan label karena adanya tindakan perilaku menyimpang. Jika masyarakat tidak menyebut sebuah tindakan sebagai perilaku menyimpang, maka tanda atau label itu tidak ada. (Purnama, 2016).

Hasil kesimpulan variabel ini juga menunjukan bahwa prosentase stigma Tanda dan Isyarat berkategori baik, sebanyak $84,6 \%(n=364)$. Dalam varibael ini dapat 
dikatakan baik karena masyarakat tidak memberi cap atau label kepada orang yang terinfeksi COVID-19, karena dengan memberikan label nama seseorang itu akan menjadi buruk dilingkungan dan nama itu akan terus menempel pada dirinya meskipun seorang itu sembuh dari penyakitnya, jadi masyarakat tidak mengatakan orang yang terinfeksi virus ini merupakan seorang yang mempunyai cap atau label buruk, dapat diartikan jika masyarakat memberikan cap atau label tersebut akan menimbulkan nama dilingkungannya menjadi buruk juga.

\section{Gambaran Stigma Masyarakat Sterotip tentang COVID-I 9 di Kelurahan Cepokomulyo Kecamatan}

\section{Kepanjen Kabupaten Malang}

Tabel 4. Hasil distribusi frekuensi responden berdasarkan stigma masyarakat Sterotip tentang COVID-19 di Kelurahan Cepokomulyo Kecamatan Kepanjen Kabupaten Malang $(n=364)$

\begin{tabular}{cccc}
\hline Variabel & $\begin{array}{c}\text { Katagori } \\
\text { I Skor }\end{array}$ & Frekuensi & $\%$ \\
\hline Sterotip & Baik & 343 & $94,2 \%$ \\
& Kurang & 21 & $5,8 \%$ \\
\hline Total & & 364 & $100 \%$ \\
\hline
\end{tabular}

Sumber data : Data Primer 2020

Berdasarkan hasil penelitian dari 364 responden dapat diketahui bahwa tingkat stigma sterotip yang memiliki stigma baik 343 (94,2 \%) dan masyarakat yang memiliki stigma kurang baik 21 (5,8 \%), Median 17,00 yang berarti tingkat stigma sterotip tentang COVID-19 baik. Sterotip struktur keyakinan dan pengetahuan yang dipelajari masyarakat umum tentang suatu kelompok yang umum karena hanya sebagai perwakilan dari anggapan masyarakat umum tentang suatu kelompok sosial.

Hasil penelitian terdahulu Hasmila, stereotip sebagai representasi terang- terangan namun sederhana yang mereduksi orang menjadi serangkaian ciri karakter yang dibesar-besarkan, dan biasanya bersifat negatif (Putriyani D, 20I4). Sejalan dengan penelitian Murdianto, sterotip jalan pintas pemikiran yang dilakukan secara langsung tanpa melalui penalaran oleh manusia untuk menyederhanakan hal-hal dalam pengambilan keputusan secara cepat. Sterotip jarang kali akurat atau terpercaya, biasanya hanya memiliki sedikit dasar yang benar atau bahkan sepenuhnya dikarang-karang (Murdianto, 2018). Para humanis berorientasi psikoanalisis, menekankan bahwa sterotip secara definisi tidak pernah akurat, tetapi merupakan penonjolan ketakutan seseorang kepada orang lainnya, tanpa memperdulikan kenyataan yang sebenarnya. Hasil kesimpulan variabel ini juga menunjukan bahwa prosentase stigma sterotip berkategori baik, sebanyak $94,2 \%(n=364)$. Dalam variabel ini dapat dikatakan baik karena masyarakat tidak menilai seseorang hanya melihat dari penampilannya. Informasi tentang COVID-19 ini sudah didapatkan dalam kehidupan sehari-hari melalui media televisi, radio, koran, tenaga kesehatan oleh karena itu dengan informasi yang akurat dapat mengetahui mana yang benar, untuk pengetahuan masyarakat menjadi baik dengan pengetahuan yang baik akan menghilangkan ketakutan dan jika ketakutan itu hilang maka stigma tidak akan muncul pada masyarakat. Keyakinan masyarakat bahwa orang yang terinfeksi virus ini adalah suatu musibah yang buruk, bukan karena jarangnya beribadah atau suatu kesialan dan ketidak beruntungan dalam kehidupan.

Gambaran Stigma Masyarakat Prasangka tentang COVID-I 9 di Kelurahan Cepokomulyo Kecamatan Kepanjen Kabupaten Malang

Tabel 5. Hasil distribusi frekuensi responden berdasarkan stigma masyarakat Prasangka tentang COVID-19 di Kelurahan Cepokomulyo Kecamatan Kepanjen Kabupaten Malang $(n=364)$

\begin{tabular}{llll}
\hline Variabel & Katagori & Frekuensi & $\%$ \\
& I Skor & & \\
\hline Prasangka & Baik & 313 & $86,0 \%$ \\
& Kurang & 51 & $14,0 \%$ \\
\hline Total & & 364 & $100 \%$
\end{tabular}

Sumber data : Data Primer 2020

Berdasarkan hasil penelitian dari 364 responden dapat diketahui bahwa tingkat stigma Prasangka masyarakat yang memiliki stigma baik $313(86,0 \%)$ dan masyarakat yang 
memiliki stigma kurang 5I (I4,0\%), Median 10,00. Prasangka mempunyai kualitas suka dan tidak suka pada objek yang diprasangkainya dan kondisi ini akan mempengaruhi tindakan atau perilaku seseorang untuk berprasangka.

Berdasarkan penelitian terdahulu Sarwono, Prasangka itu sendiri berkembang karena individu mempelajarinya. Muncul dan berkembangnya prasangka ini persis sama seperti muncul dan berkembang sikap lainnya (Ilmu $R$. 2018). Sejalan juga dengan penelitian Desi P, Sesuai dengan pandangan teori belajar sosial, dimana seorang anak mempelajari prasangka dari berbagai kelompok. Anak-anak dapat mengalami proses belajar langsung karena ia mengamati bagaimana ekpresi orang tuanya, gurunya atau kelompok lainnya terhadap target prasangka. Proses belajar lain adalah melalui pengalaman yang bersifat vicarious (perwakilan). Prasangka, stigma berupa anggapan masyarakat terhadap seseorang yang dianggap tercela padahal belum tentu kebenarannya, sikap prasangka merupakan sikap yang cenderung emosional tidak rasional (Putriyani D, 2014).

Hasil kesimpulan varibel ini menunjukkan bahwa preqqsentase stigma masyarakat berkategori baik pada variabel prasangka, sebanyak 86,0 \% $(n=364)$. Dalam variabel ini dapat dikatakan baik dikarenakan masyarakat bersikap rasional dimana suatu tindakan yang dilakukan dengan berdasarkan pertimbangan yang baik dan juga untuk tujuan yang baik, dalam keadaan seperti ini sebagian banyak masyarakat juga sudah tidak terlalu cemas dan tidak menjauhi orang yang pernah terinfeksi COVID-19, sehingga masyarakat bisa bersikap seperti biasa di lingkungannya .

\section{Gambaran Stigma Masyarakat Diskriminasi tentang COVID-19 di Kelurahan Cepokomulyo Kecamatan Kepanjen Kabupaten Malang}

Tabel 6. Hasil distribusi frekuensi responden berdasarkan stigma masyarakat Dikriminasi tentang COVID-19 di Kelurahan Cepokomulyo Kecamatan Kepanjen Kabupaten Malang $(n=364)$

\begin{tabular}{llll}
\hline Variabel & Katagori & I & Frekuensi \\
& Skor & & \\
& & & \\
\hline Diskriminasi & Baik & 258 & $70,9 \%$ \\
& Kurang & 106 & $29,1 \%$ \\
\hline Total & & 364 & $100 \%$
\end{tabular}

Sumber data : Data Primer 2020

Berdasarkan hasil penelitian dari 364 responden dapat diketahui bahwa tingkat stigma Diskriminasi masyarakat yang memiliki stigma baik 258 (70,9 \%) dan masyarakat yang memiliki stigma kurang 106 (29,I \%), Median 8,00. Pada dasarnya diskriminasi, pembedaan perlakuan yang tidak adil atau tidak seimbang yang dilakukan untuk membedakan terhadap perorangan, perlakuan tidak adil dari seseorang yang akhirnya mengarah pada beberapa bentuk penolakan atau pengucilan.

Dari hasil penelitian Sahrul, bahwa diskriminasi merujuk kepada pelayanan yang tidak adil terhadap individu tertentu, dimana layanan ini dibuat berdasarkan karakteristik yang diawali oleh individu tersebut, lalu ditunjukkan dalam tindakan yang terbuka atau rencana tertutup untuk menyingkirkan, menjauhi atau membuka jarak baik bersifat fisik maupun sosial dengan kelompok tertentu (Sarifudin, 2016). Didukung juga dari penelitian Hasmila, diskriminasi suatu kejadian yang biasa dijumpai dalam masyarakat, seperti individu diberi layanan yang tidak adil karena mereka menderita penyakit, meskipun mereka sudah sembuh tetapi masih sebagian orang menolaknya, ini disebabkan karena kecenderungan manusia untuk membeda-bedakan yang lain. Dengan berkomunikasi ataupun bersosialisasi, masyarakat diharapkan bisa terbuka pikirannya yang nantinya membuat situasi dan kondisi orang menjadi lebih baik (Reysa, 2016). Hasil penelitian pada variabel ini juga menunjukan bahwa prosentase stigma berkategori baik pada variabel Diskriminasi, sebanyak 8I,9\% $(n=364)$. Dalam variabel ini bisa dikatakan baik karena masyarakat sudah mengerti bahwa orang yang dinyatakan sembuh dari virus ini kemungkinan besar tidak menularkannya dan masyarakat sudah tidak mengasingkan atau menjauhi orang yang sembuh dari COVID-19 di lingkungan. Dalam variabel ini 
untuk stigma yang berkatagori kurang tertinggi dari variabel lainnya dikarenakan sebagian masyarakat masih ada yang menolak jasad orang yang terinfeksi COVID-19 untuk dimakamkan dilingkungannya

\section{KESIMPULAN}

Berdasarkan hasil penelitian yang telah dilakukan, menunjukan bahwa prosentase stigma berkategori baik pada variabel Diskriminasi, sebanyak 81,9\% $(n=364)$. Dalam variabel ini bisa dikatakan baik karena masyarakat sudah mengerti bahwa orang yang dinyatakan sembuh dari virus ini kemungkinan besar tidak menularkannya dan masyarakat sudah tidak mengasingkan atau menjauhi orang yang sembuh dari COVID-19 di lingkungan

\section{DAFTAR PUSTAKA}

Adhikari, Sha Meng, Yu-ju Wu, Yu-Ping Mao, Rui-Xue Ye, Qing- Zhi Wang, Chang Sun, Sean Sylva, Scoott Rozelle, Hein Raat, Huan Zhou. 2020. 'Epidemiology, Causes , Clinical Manifestation and Diagnosis, Prevention and Control of Coronavirus Disease ( COVID-19) During the Early Outbreak Period: a Scoping Review', BMC, 29(9), pp. I-I2.

Azmi, F. 2020. Kasus Corona di Jatim Tembus 7.078, Ini Peta Persebarannya', Detik News, April. Available at: https://m.detik.com/news/berita-jawa-timur/d4960599/kasus-corona-di-jatim-tembus-7078-inipeta-persebarannya.

Biswas Debashish, Fosiul, Sanghvi Tina, Roy Sumitro, Luby P. Stephen, E. Leanne. 2017. 'Provision versus promotion to develop a handwashing station: the effect on desired handwashing behavior'. BMC Public Health, (May). doi: I0.I I86/s I 2889-0I7-43 I6-6

BNPB. 2020. Gugus Tugas Percepetan Penanganan COVID19, Badan Nasional Penanggulangan Bencana. Available at: www.covid 19.go.id.

Dahlan, U. 20I3. Buku Ajaran Ketrampilan Dasar Praktik Kebidanan. Malang: Inti Media.

Hulland, K. R. S, Leontsini Elli, U.Leanne, Afroz Aasma, Dutta C Notan, Nizame A Fosiul, Luby P Stephen, Ram Pavani, Winch Peter. 20I3. 'Designing a handwashing station for infrastructurerestricted communities in Bangladesh using the integrated behavioural model for water, sanitation and hygiene interventions (IBM-WASH)', BMC Public Health. BMC Public Health, I3(I), p.

I. doi: $\quad|0| 186 /.|47|-$
$2458-\mid 3-877$.

Kemendagri RI. 2020. 'PP No.20 Tahun 2020 tentang Percepatan Penanganan Corona Virus Disease 2019 Di Lingkungan Pemerintah Daerah'.

KEMENDES. 2020. 'Surat Edaran No. 8 Tahun 2020 tentang Desa Tanggap COVID-19 dan Penegasan Padat Karya Tunai Desa'.

Notoatmodjo, S. 2013. Ilmu Kesehatan Masyarakat. Jakarta: Rineka Cipta.

PERPRES. 2020. PP No. 21 Tahun 2020 Tentang Pembatasan Sosial Berskala Besar Dalam Rangka Percepatan Penanganan Corona Virus Disease 2019 (COVID-19)'. 